Ansell N (2014) 'Challenging empowerment: AIDS-affected southern African children and the need for a multi-level relational approach' Journal of Health Psychology 19(1) 22-33

\title{
Challenging empowerment: AIDS-affected southern African children and the need for a multi-level relational approach
}

Nicola Ansell, Brunel University

\begin{abstract}
Critics of empowerment have highlighted the concept's mutability, focus on individual transformation, one-dimensionality and challenges of operationalisation. Relating these critiques to children's empowerment raises new challenges. Drawing on scholarship on children's subjecthood and exercise of power, alongside empirical research with children affected by AIDS, I argue that empowerment envisaged as individual self-transformation and increased capacity to act independently offers little basis for progressive change. Rather it is essential to adopt a relational approach that recognises the need to transform power relationships at multiple levels. This analysis has implications for our wider understanding of empowerment in the $21^{\text {st }}$ century.
\end{abstract}

In this paper I explore whether 'empowerment' is a helpful approach to addressing problems facing marginalised children, drawing on research with children compelled to move home due to southern Africa's AIDS pandemic. As a social geographer, engaging with the field of international development, I embed this in discussion of recent critiques of the concept, and suggest its application to children offers a useful challenge to broader thinking about empowerment. Two attributes of social geography shape its contribution to these debates. First, in contrast to development studies, which focuses almost exclusively on the 'global South', social geography is sensitive to the spatial construction of difference, but does not dichotomise the globe. Rather, the application and interrogation of theory across diverse settings is fundamental to conceptual development within the discipline. Second, as a social science, geography has variously engaged with the social and the psychological, the collective and the individual. In the $21^{\text {st }}$ century a growing body of work has sought to reconcile these perspectives. The paper begins with a general discussion of empowerment and its critiques, drawing particularly on work from feminist social geography and development studies. I then consider how these critiques play out when applied to the empowerment of children, drawing on geographical scholarship on children's subjecthood and on children's exercise of power. I relate these ideas to an empirical case study, drawing conclusions that reflect on wider implications for understanding empowerment in the $21^{\text {st }}$ century.

\section{Empowerment and its critiques}

Viewed as 'the means by which individuals, groups and/or communities become able to take control of their circumstances and achieve their goals' (Adams, 1996:5), empowerment has, since the late 1980s, gained 'almost unimpeachable moral authority' (Cornwall and Brock, 2005:1043). The concept pervades international development, peppering such influential documents as the Millennium Development 
Ansell N (2014) 'Challenging empowerment: AIDS-affected southern African children and the need for a multi-level relational approach' Journal of Health Psychology 19(1) 22-33

Goals ${ }^{1}$ and Poverty Reduction Strategy Papers ${ }^{2}$, arguably because it provides legitimacy, conferring 'goodness and rightness' (Cornwall and Brock, 2005:1045) on those deploying it.

While the term retains currency in policy circles, it has long been subject to critique from academics for the vagueness and inconsistent uses of the term. Empowerment is a familiar concept in diverse quarters: Cornwall and Brock (2005) cite feminist scholarship, the Christian Right, New Age self-help manuals and business management. Inevitably, it means different things to different users (and different audiences). This increases the concept's flexibility, ensuring its wide acceptability; it also both de-politicises the term (which need no longer refer to a radical alteration in power relations) and allows it to be deployed in ways that are highly political (for instance to justify neoliberal policies) (McEwen and Bek, 2006).

The diverse understandings of empowerment, and associated political uses, are framed by very different concepts of power. The empowerment concept emerged from recognition that groups of people were marginalised through oppressive power relations and that their situation could only be ameliorated by addressing such relations. Over time, the way power has been conceptualised in relation to empowerment has altered.

In the 1990s, drawing on Foucault, power came to be viewed less in modernist dichotomous terms of powerful/powerless (Kesby, 2005). The (albeit partial) application of this rethinking to notions of empowerment has, I would argue, challenged the concept's political salience in contradictory ways. Three issues are significant: whether empowerment is an individual or collective process; its multidimensionality and its instrumentalisation. These are outlined below and subsequently considered in relation to children.

Power relates to 'the ability of one agent to affect the actions or attitudes of another' (Corbridge, 2009:575). According to Foucault, however, power is not a possession or a commodity but rather a process. It is productive and diverse, not a unidirectional force but an effect of networked discourses and practices that produce ways of being, acting and thinking (Kesby, 2007). Moreover, both dominating and resisting power are fragmentary, uneven and inconsistent, with individuals and groups often supporting some aspects of the social order while opposing others, and even 'successful' resistance sometimes reinforcing rather than dismantling certain forms of domination (Sharp et al., 2000).

This poststructuralist view of power, while not viewing power as an individual attribute, nonetheless supported a shift in understandings of empowerment among feminist geographers and development

\footnotetext{
${ }^{1}$ The Millennium Development Goals are eight targets that United Nations member states and international development organisations set in 2000. They include, for instance, eradicating extreme poverty, achieving universal primary education and combating HIV and AIDS by 2015.

${ }^{2}$ The international financial institutions require countries to produce Poverty Reduction Strategy Papers before they are considered for debt relief. While in theory 'country driven', in practice these must enshrine a neoliberal approach.
} 
Ansell N (2014) 'Challenging empowerment: AIDS-affected southern African children and the need for a multi-level relational approach' Journal of Health Psychology 19(1) 22-33

studies scholars from collective action to individual transformation (Rowlands, 1997). Drawing on the work of Butler (1990), which emphasised how subjectivities are fluid, decentred and always in the process of becoming, empowerment came to be understood as the construction of new subjectivities. However, rather than recognising that subjectivities are socially constructed, empowerment was increasingly viewed as internal to the individual. The emphasis thus switched from 'power over' to 'power within' (self-respect, self-awareness, confidence, dignity); 'power with' (solidarity, alliances, coalitions); and 'power to' (capacity-building, decision-making and leadership) (Oxaal and Baden, 1997, Rowlands, 1997). 'Power within' was considered core, a necessary precursor to any involvement in collective and /or political action (Rowlands, 1997). Rooted in these conceptualisations, empowerment became understood as a process whereby individuals break free of dominating power relations that frame their lives in order to pursue their own goals. This view of empowerment as self-transformation (Rai, 2002), while at one level accepting a poststructuralist view of power as dispersed, actually rests on a highly modernist individualism and belief in self-knowledge.

The emphasis on individual empowerment has not gone unchallenged. Numerous scholars have questioned whether change can result from individual transformation alone, without wider structural change (Desai, 2002; Parpart et al., 2002; Stromquist, 2002). Social work professor, Pease (2002) suggests it is unclear how changes in individual consciousness can contribute to social change. Problematically, the individualistic approach to empowerment has been co-opted by neoliberal institutions. For Pease (2002), the focus on developing individual capacities has reduced social relations to the interpersonal level, obscuring wider power relations in society. Seen in this way, empowerment resembles the concept of self-determination with its emphasis on individual responsibility. Thus, as geographers McEwen and Bek (2006:1021) point out, 'where empowerment was once a subversive, emancipatory activist tool, it now forms one of the building blocks of neo-liberal governance'. The World Bank in particular has appropriated and reworked the term to refer, for example, to 'poor people being empowered through the marketisation of services that were once their basic right' (Cornwall and Brock, 2005:1057).

One response to the opposition between individual and collective understandings of empowerment has been to conceptualise a continuum. Rocha (1997), for instance, proposed empowerment as a spectrum with 'Atomistic Individual Empowerment' at one end and 'Political Empowerment' at the other. This perspective is, however, criticised for neglecting other dimensions of conceptual difference, such as the underlying philosophy and the processes involved (Jennings et al., 2006). Similarly, social psychologist Cornish (2006) is critical of viewing empowerment as a one-dimensional 'increase in power', a tendency she blames on the interest in measuring empowerment. Cornish argues that different activities require qualitatively different forms of empowerment, thus empowerment is only meaningful when defined in relation to a particular activity. A person can be empowered in one domain but not another (indeed, empowerment in one domain can mean disempowerment in another). Women attending handiwork classes, for instance, are not empowered in the same way as those learning to argue with politicians. Importantly, the relationship between the domains is not hierarchical. Equally, empowerment in one spatial context does not imply empowerment in another (Kesby, 2005). The multiplicity of power relations and need for empowerment to be multidimensional merits further attention. 
Ansell N (2014) 'Challenging empowerment: AIDS-affected southern African children and the need for a multi-level relational approach' Journal of Health Psychology 19(1) 22-33

Lastly, debate about empowerment has focused on whether and how empowerment might be achieved. Strategies for empowerment vary greatly and are shaped by political, historical and cultural contexts (Bodur and Franceschet, 2002). However, there are fundamental questions concerning whether it is possible purposefully to empower another person. This debate rests partly on conceptualisations of power: some argue that to empower another implies power is viewed as a transferable commodity. If this view is rejected (power cannot be given), and empowerment is seen as fundamentally rooted in 'power within', an empowerment strategy can only seek to establish suitable circumstances for selftransformation. I would argue that commodity transfer or self-transformation are not the only perspectives: questions concerning relationality, instrumentality and semantics merit further consideration. Significantly, moreover, one cannot easily predict where social change will emerge (Desai, 2002).

A number of scholars have drawn on Foucault's concept of governmentality to add to this debate. Foucault describes how practices of power regulate and produce subjects through self-regulation and self-discipline - we evaluate and act upon ourselves, so that those in authority do not have to (Cruikshank, 1993). This idea has been applied to empowerment: through empowerment strategies people are encouraged to change themselves to become the type of active, engaged citizens that modern society desires. Pease (2002) suggests that practices of empowerment may serve to perpetuate hierarchical power relations, describing empowerment as a 'subtle refinement of domination, masked by the respectability of a liberatory discourse' (p.138).

To summarise, feminist research from geography and development studies has worked with the concept of empowerment and, influenced by Foucault's conception of power, has tended to focus on individual transformation as pivotal. However, within the same field of literature and often from a poststructuralist perspective, critiques of empowerment are widely expressed. The concept's mutability, the focus on individual transformation, oversimplification/one-dimensionality and challenges of operationalisation all limit empowerment's radical potential in relation to transformation of gender relations. Application of the concept to children raises further issues in all of these areas, with implications for feminist geography and development studies, as well as for community health psychology.

\section{Marginalisation, identity and discourse: a rationale for the empowerment of children}

In developing the empowerment concept, feminist scholarship recognised that women's subordination was founded in power relations that were at least partially distinct from the class relations that were fundamental to earlier critical scholarship. The concept was subsequently taken up by scholars working with other marginalised groups: ethnic, religious and sexual minorities, disabled people. Each of these identities was seen to be subordinated through a distinct set of historically, politically and culturally embedded power relations. Marginalisation could be addressed only by changing these power relations, but since those wielding power would not relinquish it voluntarily, any solution must come from 'below' 
Ansell N (2014) 'Challenging empowerment: AIDS-affected southern African children and the need for a multi-level relational approach' Journal of Health Psychology 19(1) 22-33

- from the marginalised themselves. Hence empowerment was required to enable marginalised people(s) to address their own needs, through economic or political means, individually or collectively.

In the 1990s the attention of social scientists was drawn to another identity group: children. In classic terms, children are among the most marginalised in (any) society. They lack voice, access to the public realm, control over economic resources. Inevitably, children came to be seen by some as needing empowerment. Interest in children's empowerment connects with two developments occurring from the late 1980s: the emergence of a new paradigm in childhood studies - the 'new social studies of childhood' - and the adoption in 1989 of the UN Convention on the Rights of the Child.

The new social studies of childhood, developed principally by social anthropologists and sociologists, is characterised by two key tenets: that childhood is a social construction, historically and culturally variable and amenable to change; and that children are social actors, engaged in constructing their own lives (James and Prout, 1990; James et al., 1998; Mayall, 1994). It encompasses work that has viewed children as a 'minority group', similar to other minorities (James et al., 1998). These three elements are connected: the discursive construction of childhood as passive and devoid of agency is considered largely responsible for their marginalisation, limiting their capacity to act in their own interests.

The new social studies of childhood is a normative discourse, which seeks to 'recover' children's agency in order to elevate their position in society (James and Prout, 1990). Children's marginalisation is considered an outcome of their discursive representation as powerless, as much as their lack of practical capacity to act. Thus studies in this tradition have drawn attention to children's active contributions to society, such as their participation in economic production (e.g. Nieuwenhuys, 1993; Robson, 2004), as well as examples of children acting independently of, or in opposition to, cultural norms (Montgomery, 2001; Young, 2003).

While much research has focused on uncovering and celebrating existing examples of children's agency to construct new discursive representations, the new social studies of childhood has also inspired efforts to enhance children's capacity to act in their own interests. These activities draw support from the UN Convention on the Rights of the Child, which affords children the right to participate in decisions about their lives. Framed explicitly in terms of empowerment or alternatively 'enhancing agency', most such strategies resemble those employed in relation to other minority groups.

\section{Children as a challenge to concepts of empowerment}

While children have been studied as a minority group similar to any other, a number of features of childhood render it a distinct type of category. Constructions of childhood undoubtedly differ socially and culturally, but childhood as an identity cannot be constructed entirely free from the constraints of 'real' embodied children (Prout, 2005). Children's relative powerlessness is partly attributable to inherent distinctions from (most) adults. Children are also socially embedded in distinctive ways: childhood is a universal life stage (everyone is or has been a child), and this shapes adults' responses to children; moreover, childhood is not a perpetual status as most children become adults. These features 
Ansell N (2014) 'Challenging empowerment: AIDS-affected southern African children and the need for a multi-level relational approach' Journal of Health Psychology 19(1) 22-33

of childhood mean that efforts to apply the concept of empowerment to children raise significant questions for the concept itself, intervening in the three areas of debate outlined above.

\section{a. Individual or collective? Questioning the independent subject}

The notion that empowerment must take place at the individual level and be constituted through selftransformation of individual subjectivity rests on an assumption of liberal subjecthood. This Hobbesian subject is a 'fully independent being whose rights are constituted in an antagonistic relationship to the rights of others' (Ruddick, 2007b:628). One of the clearest challenges to this liberal subject is that posed by the child. Indeed, for social geographer Ruddick (2007a, 2007b) the child is the limit to the liberal subject, denied juridical and political subjecthood by law and, in the case of very young children, unable to articulate individual interests, let alone live independently.

By positioning individual subjects in antagonistic terms, a liberal perspective requires that a voiceless subject be spoken for through a form of ventriloquism (Ruddick, 2007a). Ruddick describes, for instance, how courts increasingly impute the 'wishes' of foetuses, ruling on whether they would wish to live and defending their perceived interests in opposition to their prospective mothers. Strikingly, older children who are able to express views are also spoken for. Ruddick cites American children diagnosed with 'Parental Alienation Syndrome' whose expressed wishes in relation to family living arrangements are dismissed as evidence of 'brainwashing'. The more strongly expressed their preference, the more this is taken as persuasive evidence that they do not know their real wishes. The view that a child cannot truly know him/herself results in a proliferation of caregivers claiming to speak on their behalf and enact their 'best interests' rather than their stated wishes. Thus children's voices are almost always filtered through the agendas of others.

While Ruddick's focus is North America, similar processes permeate activities geared toward children's empowerment elsewhere. White and Choudhury (2007:531) argue that in Bangladesh, for instance, 'the introduction of "children's participation" within development programmes does not simply challenge existing forms of power; it also becomes itself a means through which power is expressed'. Critical of the liberalism being promoted, they ask 'what forms of agency are being promoted and whose interests they serve'.

To 'empower' children seemingly implies enabling them to make their voices heard and ensure their interests are addressed. This corresponds to an assertion of their independent subjecthood (White and Choudhury, 2007). As Ruddick (2007a) points out, in emphasising social agency, the new social studies of childhood represents a move toward theorising the child as a liberal subject. This subjecthood is, however, confined to accepted spaces such as playgrounds 'where their voice is not complicated by its relationship to "others"' (p. 515). Beyond such limited arenas, the ventriloquism continues. Ruddick cautions against liberal constructs of children's rights, and argues that the effect of celebrating children's agency may be 'to re-enshrine a liberal concept of the individual, antagonistically constituted subject' (p.515) while failing to address problematic aspects of children's relationships to others. She asserts: 'the paradoxical definition of childhood in relation to liberal notions of the subject [has] 
Ansell N (2014) 'Challenging empowerment: AIDS-affected southern African children and the need for a multi-level relational approach' Journal of Health Psychology 19(1) 22-33

rendered children's rights a dangerous political terrain, potentially open to a ventriloquist form of representation which enhances the authority of the ventriloquist and is used to undermine not only the rights claims of others but of children themselves' (Ruddick, 2007b:638).

Instead of a liberal conceptualisation, it is helpful to recognise that subjecthood can be dispersed across actors. Ruddick (2007b) points out that caregiving arrangements for children are a site where aspects of the subject are distributed across a collectivity, with diverse caregivers performing aspects such as reasoning and decision-making for the child.

Rejecting liberal subjecthood and focusing instead on intersubjective relationships defuses the question of whether empowerment must start with the individual; empowerment is conceived as beginning in relationships rather than the individual psyche. While undermining one ongoing debate, such a relational perspective also poses a challenge for conceptualising empowerment.

\section{b. Dimensions of power}

Gallagher (2008) relates a research encounter with children in a Scottish primary classroom. Rather than complying with the planned activities, the children exploited the opportunity to avoid their usual school work, subverted the exercise in pursuit of their own objectives and demonstrated gendered power relations among themselves; forms of 'colonization, appropriation and domination [rather] than ... participation' (p.143). Planned as 'empowering' participatory research, the events highlighted both that children already exercise power in relation to adults and that they are not necessarily interested in the forms of empowerment others might plan for them. In a southern African context, I experienced similar (albeit tactically subtler) resistance to participatory research from secondary school students (Ansell, 2001).

Research with children often seems to confirm Foucault's view of 'power as encompassing a diverse array of unstable, ambivalent forms of action' (Gallagher, 2008:145). If power always engenders resistance, adult power will always have to contend with subversion; it is not absolute but precarious. Nonetheless, children's acts of subversion may challenge but cannot directly transform the national or international scale policies that shape their lives (Ansell, 2009).

Gallagher raises an interesting related issue: the desirability of power. Those writing about empowerment tend to view power negatively. Adults' exercise of power in relation to children is seen as harmfully repressive. However, Gallagher points out that for Foucault, 'power is not an evil'. While power is potentially dangerous, it is also productive and an essential part of social life; it is important to avoid negative outcomes of domination, but not power itself. This would suggest that adults' exercise of power in relation to children is not inherently problematic. Moreover, the exercise of power by children is not inevitably positive or even benign. Resistance to domination can itself use and reproduce dominating strategies. This raises questions of whether adults should exercise power to challenge and suppress forms of dominating power (such as masculinism) wielded by children. It also suggests 
Ansell N (2014) 'Challenging empowerment: AIDS-affected southern African children and the need for a multi-level relational approach' Journal of Health Psychology 19(1) 22-33

empowering children may promote exercise of power in ways that fail to address significant forms of domination (including at policy level) and may even reinforce domination.

\section{c. Instrumentalising children's empowerment}

Children, then, always exercise some forms of power. However, access to public decision-making arenas almost always requires adult sanction. Regardless of how much their self-esteem is boosted, children can seldom seize the initiative on public policy. This highlights the relationality of their empowerment. While power is not a commodity handed to children through an empowerment process, children's empowerment does require conditions to be put in place. It is situational. And as Ruddick has pointed out, adults determine the situations, and tend to confine these to, for example, spaces of children's leisure, reserving the policy processes that impact on most areas of children's lives to adults.

Reviewing studies of children's empowerment programmes is revealing. These almost always relate to empowerment in a confined setting; allowing young people a decision-making role in a school, youth club or workshop, for instance. Many interventions promote empowerment where young people's relative powerlessness is considered an obstacle to something deemed socially desirable, for instance resisting smoking or engaging in premature or unsafe sex. Berg et al. (2009), for instance, tell readers 'Youth Action Research for Prevention (YARP), a federally funded research and demonstration intervention, utilizes youth empowerment as the cornerstone of a multi-level intervention designed to reduce and/or delay onset of drug and sex risk, while increasing individual and collective efficacy and educational expectations.' Such programmes are clearly more concerned with enabling individuals to fit social expectations, than to achieve social transformation. By contrast, Jennings et al. (2006:40) suggest the purpose of empowerment should be 'to support and foster youth contributions to positive community development and sociopolitical change, resulting in youth who are critical citizens, actively participating in the day-to-day building of stronger, more equitable communities'. However, while this may be a laudable and progressive goal, it still reflects an adult vision of society. It is remarkably difficult to envisage how to promote truly open forms of empowerment.

\section{Empirical case: Young AIDS migrants}

In this section I explore the application of the concept of empowerment to the situation of children migrating as a consequence of southern Africa's AIDS pandemic. I draw on research I conducted with Lorraine van Blerk (nee Young) in Lesotho and Malawi in 2001/2 (see van Blerk and Ansell, 2006). Focusing on whether empowerment might appropriately be considered a solution to the problems the children identified through the research, I question whether their difficulties are attributable to specific power relations and, if so, the nature of those power relations. I also consider what empowerment might mean in this context and how it could be instrumentalised. 
Ansell N (2014) 'Challenging empowerment: AIDS-affected southern African children and the need for a multi-level relational approach' Journal of Health Psychology 19(1) 22-33

Childhood in Lesotho and Malawi is, of course, constructed in culturally specific ways. Relative to most Western contexts, children commonly exercise an unusually high degree of practical autonomy from older kin (in Lesotho, for instance, pre-teenage boys spend weeks away from home herding livestock in the company only of their peers). However, children are not generally expected to express their views to adults or to contribute to significant decisions about their lives (Ansell and van Blerk, 2004). Such constructions do not go uncontested; southern Africa's alarmingly high HIV prevalence is challenging expectations concerning children's care and behaviour (Kesby et al., 2006).

Most children who participated in the research had had to move home - generally either with family members or between extended family households - following a parent or other close relative falling sick or dying from AIDS-related illnesses. Often the immediate trigger was economic, such as unemployment or inability to pay school fees. Many described difficulties fitting into their new homes, schools and communities. In many cases the residential arrangements ultimately failed and the children had to move again, with further problematic consequences. Some were economically exploited by aunts or uncles, or mistreated relative to other children. Many expressed a preference to live with their grandparents, but this often proved impossible because grandparents' resources were inadequate. Very few were involved in decisions about where they would live.

I discuss this research here because the term 'empowerment' appeared among our policy recommendations. Specifically, we framed these recommendations around two themes: 'enabling households' and 'empowering children'. Our analysis of children's difficulties and the solutions to them lay broadly at two levels: a 'top-down' perspective on the structural and policy conditions impinging on households and a 'bottom-up' view that children needed to be involved in decision making. Interestingly, it was only the latter that we referred to in terms of 'empowerment'.

In looking again at this example, it seems clear that the children's situation reflected power relations at both levels; or rather that the power relations involved are complex and bind together children, their families, communities, governments and wider political economic conditions. Certainly most children who participated in the research had had no influence over the decision that they should move home. However, the requirement for them to move was clearly a product of the fact that household members had become infected with HIV (an outcome of poverty and gendered power relations); that effective affordable treatments were not available (reflecting global economic power relations); and that welfare systems failed to support those who became sick or unemployed, or to support grandparents to care for grandchildren (an outcome of public policy decisions and a global economic system that impoverishes rather than supports cash-strapped governments). ${ }^{3}$

To seek to understand children's situations in terms of their lack of power tends to draw attention to their immediate contexts (family networks in particular) and less directly to their lack of public voice, or the failure of those making significant decisions (whether in relation to sexual behaviour or public policy)

\footnotetext{
${ }^{3}$ It is noteworthy that in the twelve years since the research was conducted, these contexts have shifted, particularly through the introduction of effective and affordable medicines and of social protection policies, including in Lesotho old age pensions.
} 
Ansell N (2014) 'Challenging empowerment: AIDS-affected southern African children and the need for a multi-level relational approach' Journal of Health Psychology 19(1) 22-33

to consider their (often unspoken) interests. If empowerment is seen only in terms of addressing the immediate power relations through which children are subordinated, many factors contributing to their difficult situations will not be addressed. Moreover, attributing children's difficulties to the fact that they are not invited to participate in decisions about where they live not only suggests that the power relations in which they are embedded are 'bad' for them, it also blames families that are under extreme constraint.

It should be mentioned at this stage that while most of the children we talked to said that they were not, but would have liked to have been, consulted (although many accepted that there were few options available), some children had in fact moved on their own initiative. Often this was because an initial move had proved particularly problematic, or their situation in their new home deteriorated. Some children had taken a bus to a grandparent's home and pleaded to be allowed to stay; others travelled to the cities to live with peers on the streets. In conventional terms this exercise of agency is perhaps a sign of 'empowerment' (at least at the individual level). However, it is very much a response to a difficult situation and not a way of inhibiting such situations from occurring.

Enabling children to move independently in this way was not what we meant by 'empowering children' in 2002. Rather, what we referred to was a series of actions that might be taken by children's families in order to allow children's voices to be heard and reduce the risk of them being sent without warning to a household and place with which they were unfamiliar. Specifically we recommended familiarising children with the place and people they were moving to; including children in family discussions regarding their migration preferences; and maintaining ties with kin to ensure that children do not become distanced from their family and cultural heritage. 'Empowerment' was not about enabling children to act individually (or even collectively) in their own interests, but rather making such action unnecessary. Although we were not explicit about this, our view of empowerment saw it rooted in relationships. The children's situations were fundamentally shaped by their relationships with others, particularly kin, although these relationships were often impermanent and were highly fluid. Thus those 'enacting' children's empowerment were envisaged to be adult family members (one might argue that it is these adults who need empowering, to address the economic and political subordination that inhibits their capacity to act in the interests of younger family members), and empowerment was envisaged as an outcome of changes in relationships; changes in the ways adult relatives engage with children and solicit their views.

The young AIDS migrants' difficulties can be attributed to power relations through which they were subordinated. These included economic power relations that impinged on their governments, schools and families, as well as on their own lives, requiring them to engage in economic activities for their new households, and cultural practices that meant their voices were not heard or taken seriously in relation to important aspects of their lives in international or national arenas or in their own families.

Empowerment, if it is to be meaningful, must be about shaping all of these conditions that frame decisions about children's lives, not simply working directly with children to promote their enlightened self-transformation to enable them to act independently or collectively. This is about social and economic change that realistically cannot begin with children. It is about changing the way society treats children at household, community and national levels. It is about links between social norms and 
Ansell N (2014) 'Challenging empowerment: AIDS-affected southern African children and the need for a multi-level relational approach' Journal of Health Psychology 19(1) 22-33

economic structures; about ways in which adults expect to treat children that partially relate to economic constraints, as well as strong economic / material constraints that affect how children are treated. 'Empowering children' to decide where they live will not in itself transform society - the outcomes may affect immediate wellbeing, but empowerment must go beyond this. Instrumentalising such change is of course an immense challenge.

\section{Conclusions}

In this paper I have argued that power relations are at the root of some of the difficulties that marginalised children face, but that the way of addressing children's marginalisation is not empowerment envisaged as individual self-transformation and increased capacity to act independently on the part of the child. In any society, much of that comes simply with growing up. Rather, there is a need for transformation of the power structures that shape children's lives, in part to take children's interests seriously at all levels; in part to support impoverished families that are responsible for such children. The power relations that are responsible for children's situations are complex and those that children are themselves aware of and can change are not necessarily the most significant. Nor are the power relations that shape children's lives wholly problematic: power relations are necessary for society to function. Thus what is needed is not an essentialist perspective that requires empowerment 'from within' but processes that recognise that children are embedded in relationships and aspects of these relationships need to change; and that changing relationships cannot responsibly be left to children alone. Moreover, the relationships exist at multiple levels; it is not only those between children and their immediate kin that are important.

This analysis is not only of relevance to children growing up in the challenging environments of AIDSafflicted southern Africa. Exploring empowerment in relation to the lives of children also has implications for our understanding in relation to adults, and in very different contexts. If children pose a challenge to assumptions about liberal subjecthood that are fundamental to popular ideas of empowerment, are there adults too, to whom such assumptions cannot apply? Many health challenges undoubtedly limit adults' capacity to perform liberal subjecthood. From this position we need not move far to question the extent to which any adult can be understood as a fully self-aware autonomous agent. The social geographical critiques of children's agency and power outlined above imply that we should actually question normative adult subjecthood itself. This has clear implications for the field of community health psychology. If empowerment is understood as relational, not simply when it concerns children but also adults, the focus must be on transforming the power-laden relationships that exist at multiple levels, rather than envisaging change in the individual and empowerment 'from within'. How power structures might be transformed is beyond this paper's remit.

\section{Acknowledgements}


Ansell N (2014) 'Challenging empowerment: AIDS-affected southern African children and the need for a multi-level relational approach' Journal of Health Psychology 19(1) 22-33

I am grateful to DFID for funding for the research on which the case study is based, and to Lorraine van Blerk for her role in that research. Thanks also to Cathy Campbell and Flora Cornish for their editorial role; to Ginny Morrow and Mike Kesby as referees; and to the participants at the 'Beyond Empowerment' workshop. All provided very helpful feedback and suggestions. All errors, of course, are my own.

\section{References}

Adams R (1996) Social Work and Empowerment. London: Macmillan.

Ansell N (2001) Producing knowledge about 'third world women': the politics of fieldwork in a Zimbabwean secondary school. Ethics, Place and Environment 4: 101-116.

Ansell N (2009) Childhood and the politics of scale: descaling children's geographies? Progress in Human Geography 32: 190-209.

Ansell $\mathrm{N}$ and van Blerk L (2004) Children's migration as a household/family strategy: coping with AIDS in Lesotho and Malawi. Journal of Southern African Studies 30: 673-690.

Berg M, Coman E, Schensul JJ (2009) Youth action research for prevention: A multi-level intervention designed to increase efficacy and empowerment among urban youth. American Journal of Community Psychology 43: 345-359.

Bodur M, Franceschet S (2002) Movements, States and Empowerment: Women's Mobilisation in Chile and Turkey. In: Parpart J, Rai S, Staudt K (eds) Rethinking Empowerment: Gender and Development in a Global/Local World. London: Routledge.

Butler J (1990) Gender Trouble, Feminism and the Subversion of Identity. New York: Routledge.

Cornish F (2006) Empowerment to Participate: A Case Study of Participation by Indian Sex Workers in HIV Prevention. Journal of Community and Applied Social Psychology 16: 301-315.

Cornwall A, Brock K (2005) What do buzzwords do for development policy? A critical look at 'participation', 'empowerment' and 'poverty reduction'. Third World Quarterly 26: 1043-1060.

Cruikshank B (1993) Revolutions within: self government and self esteem. Economy and Society 22: 327344.

Desai V (2002) Informal Politics, Grassroots NGOs and Women's Empowerment in the Slums of Bombay. In: Parpart J, Rai S, Staudt K (eds) Rethinking Empowerment: Gender and Development in a Global/Local World. London: Routledge.

Gallagher M (2008) 'Power is not an evil': rethinking power in participatory methods. Children's Geographies 6: 137-150. 
Ansell N (2014) 'Challenging empowerment: AIDS-affected southern African children and the need for a multi-level relational approach' Journal of Health Psychology 19(1) 22-33

James A, Jenks C, Prout A (1998) Theorising Childhood. Cambridge: Polity Press.

James A and Prout A (eds) (1990) Constructing and Reconstructing Childhood. London: Falmer.

Jennings LB, Parra-Medina DM, Hilfinger-Messias DK, McLoughlin K (2006) Toward a Critical Social Theory of Youth Empowerment. Journal of Community Practice 14: 31-55.

Kesby M (2005) Retheorizing empowerment-through-participation as a performance in space: beyond tyranny to transformation. Signs 30: 2037-2065.

Kesby M (2007) Spatialising participatory approaches: the contribution of geography to a mature debate. Environment and Planning A 39: 2813-2831.

Kesby M, Gwanzura-Ottemoller F and Chizororo M (2006) Theorising other, 'other childhoods': issues emerging from work on HIV in urban and rural Zimbabwe. Children's Geographies 4:185-202.

Mayall B (ed) (1994) Children's Childhoods: Observed and Experienced. London: Routledge.

McEwen C, Bek D (2006) (Re)politicizing empowerment: lessons from the South African wine industry. Geoforum 37: 1021-1034.

Montgomery H (2001) Modern Babylon? Prostituting children in Thailand. Oxford: Berghahn.

Nieuwenhuys O (1993) Children's Lifeworlds: Gender, Welfare and Labour in the Developing World. London: Routledge.

Oxaal Z, Baden S (1997) Gender and Empowerment: Definitions, Approaches and Implications for Policy. Briefing prepared for the Swedish International Development Cooperation Agency.

Parpart J, Rai S, Staudt K (2002) Rethinking Empowerment, Gender and Development: An Introduction. In: Parpart J, Rai S, Staudt K (eds) Rethinking Empowerment: Gender and Development in a Global/Local World. London: Routledge.

Pease B (2002) Rethinking Empowerment: a Postmodern Reappraisal for Emancipatory Practice. British Journal of Social Work 32: 135-147.

Prout A (2005) The Future of Childhood. London: Routledge.

Rai S (2002) Political Representation, Democratic Institutions and Women's Empowerment: the quota debate in India. In: Parpart J, Rai S, Staudt K (eds) Rethinking Empowerment: Gender and Development in a Global/Local World. London: Routledge.

Robson E (2004) Children at work in rural Northern Nigeria: Patterns of age, space and gender. Journal of Rural Studies 20: 193-210.

Rocha EM (1997) A ladder of empowerment. Journal of Planning Education and Research 17: 31-44.

Rowlands J (1997) Questioning empowerment: working with women in Honduras. Oxford: Oxfam. 
Ansell N (2014) 'Challenging empowerment: AIDS-affected southern African children and the need for a multi-level relational approach' Journal of Health Psychology 19(1) 22-33

Ruddick (2007a) At the Horizons of the Subject: Neo-liberalism, neo-conservatism and the rights of the child Part One: From 'knowing' fetus to 'confused' child. Gender, Place and Culture: A Journal of Feminist Geography 14: 513-527.

Ruddick (2007b) At the Horizons of the Subject: Neo-liberalism, neo-conservatism and the rights of the child Part Two: Parent, caregiver, state. Gender, Place and Culture: A Journal of Feminist Geography 14: 627-640.

Sharp J, Routledge P, Philo C, Paddison R (eds) (2000) Entanglements of Power: Geographies of Domination / Resistance. London: Routledge.

Stromquist N (2002) Education as a Means for Empowering Women. In: Parpart J, Rai S, Staudt K (eds) Rethinking Empowerment: Gender and Development in a Global/Local World. London: Routledge.

Van Blerk L and Ansell N (2006) Children's experiences of migration: Moving in the wake of AIDS in southern Africa. Environment and Planning D: Society and Space 24: 449-471.

White SC, Choudhury SA (2007) The politics of child participation in international development: the dilemma of agency. European Journal of Development Research 19: 529-50.

Young L (2003) The place of street children in Kampala, Uganda: marginalisation, resistance and acceptance in the urban environment, Environment and Planning D: Society and Space 21: 607-628. 